\title{
Metodologias para Avaliação da Estabilização/Solidificação (Encapsulação) de Resíduos Industriais para Uso em Matrizes Cimentícias, Poliméricas e Cerâmicas e para Desenvolvimento de Produtos para a Construção Civil
}

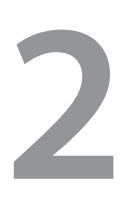

\author{
Gerusa de Cássia Salado \\ Eduvaldo Paulo Sichieri
}

\section{Introdução}

O ser humano é, por natureza, um agente transformador do ambiente. Desde a sua origem, o homem vem provocando alteraçóes na paisagem e poluindo o planeta. Após a Revolução Industrial, essas mudanças assumiram escala logarítmica em consequência dos novos processos de produção e do aumento do consumo, também exponencial, desencadeado pelo crescimento da população humana; além das enormes transformaçóes na paisagem, provocadas pelas cidades e pelos modos de produção no campo.

Nesse contexto, o crescimento populacional tem grande influência na questão da sustentabilidade, uma vez que incide no aumento do consumo em geral, da geração de resíduos e da demanda por novas construçóes (CASAGRANDE JR, 2004).

O aumento populacional e o aumento do consumo agem como devoradores dos recursos naturais e geram cada vez mais resíduos, desde a produçáo industrial até o descarte final do lixo produzido, incluindo a geração de $\mathrm{CO}_{2}$ e a poluição do solo e dos rios (EDWARDS, 2008). 
De acordo com a World Comission on Environment and Development (2007), prevê-se que até o ano de 2050 a classe média mundial (maior parcela da população consumista) triplicará, triplicando também o volume de lixo descartado.

Dessa forma, segundo Sanches (2001), a sociedade se vê entre duas opçóes: ou a descontinuidade do consumo ou uma postura menos poluidora. Em outras palavras, a humanidade se depara com a necessidade de buscar alternativas menos poluidoras tanto para a produção como para o consumo, a fim de não comprometer o futuro das novas gerações.

Vive-se, conquanto, em plena era do consumo, na qual o bem material e o individualismo se evidenciam. Como, então, atender as necessidades individuais de forma sustentável?

A lacuna formada entre o crescimento mundial e a sustentabilidade provocou as primeiras iniciativas em busca da redução da emissão dos diversos resíduos e efluentes. Eventos mundiais como a Conferência de Estocolmo ocorrida na Suécia em 1972 - e a Conferência das Naçóes Unidas sobre o Meio Ambiente (RIO-92) - realizada no Brasil, entre outros, deram origem a documentos como a Agenda 21, o Protocolo de Kyoto, a Convenção de Viena, o Protocolo de Montreal etc, que representam a preocupação da sociedade com as questôes relacionadas aos resíduos domésticos e industriais.

Para Room et al. (2004), os eventos realizados entre naçóes possuem o objetivo de firmar acordos internacionais de manutenção do meio ambiente e mostram que as mudanças são obrigatórias.

De maneira análoga, Kiperstock (2000) afirma que é necessário intervir nos processos produtivos, sugerindo a reciclagem em toda a cadeia produtiva como a forma menos onerosa para as indústrias. Rogers e Tibben-Lembke (2001), por sua vez, sustentam que cada cadeia produtiva deve ser responsável por eliminar suas emissóes internamente e apontam a reciclagem e o reaproveitamento de resíduos como estratégias ideais para a concretização desse processo.

Observando-se essas questóes, constata-se um grande desafio para o mundo industrial: produzir com o mínimo de danos ao ambiente, devendose reutilizar cada vez mais materiais descartados como lixo. 


\section{Os Resíduos Industriais e da Construção Civil e os Impactos Ambientais}

Os resíduos são produzidos em todos os estágios das atividades humanas (industrial, doméstica, hospitalar, comercial, agrícola, de serviços etc). Podem se apresentar nos estados sólido, gasoso e líquido, e variam em termos de composição e de volume conforme as práticas de consumo e os métodos de produção.

Com relação à geração de resíduos, conforme o Banco Mundial (2012), a população que mais produz lixo é a dos Estados Unidos, com aproximadamente 2,5 kg por habitante/dia; enquanto a média mundial para esse índice gira em torno de 1,2 kg por dia, para cada habitante das áreas urbanas.

Dentro desse contexto, o estudo realizado pela Associação Brasileira das Empresas de Limpeza Pública e Resíduos Especiais (Abrelpe) em 400 municípios brasileiros, intitulado Panorama dos Residuos Sólidos no Brasil de 2014, constatou que a quantia média de lixo gerado no Brasil foi de aproximadamente $1,062 \mathrm{~kg}$ por habitante/dia. No total, segundo Abrelpe (2015), o volume de resíduos sólidos urbanos produzidos no Brasil no ano de 2014 foi de 78,6 milhóes de toneladas, isto é, 2,9\% a mais que no ano de 2013, índice superior à taxa de crescimento populacional no país no período, que foi de $0,9 \%$. Considerando o período entre os anos de 2003 a 2014, a geração de lixo cresceu $29 \%$, superando a taxa de crescimento populacional urbano, que foi de cerca de $6 \%$.

Esses dados são preocupantes, uma vez que o Brasil não possui o mesmo grau de desenvolvimento dos países europeus e dos Estados Unidos, e a coleta seletiva e a reciclagem não crescem na mesma proporção do lixo gerado.

De acordo com estatísticas de Eurostat apud Smart Cities (2015), 43\% dos resíduos produzidos na União Européia são encaminhados para reciclagem ou compostagem. No Brasil, conforme Cempre (2013), somente 27\% dos resíduos recicláveis (fração seca) coletados nas cidades foram efetivamente recuperados em 2012, ou seja, foram desviados dos aterros e lixóes e retornaram à atividade produtiva.

A destinação final dos resíduos sólidos urbanos no Brasil, segundo o Censo (2010) apud Cempre (2013) é mostrada na Tabela 1. 
Tabela 1 Destinação final dos resíduos sólidos urbanos no Brasil. Fonte: Censo (2010) apud Cempre (2013).

\begin{tabular}{ll}
\hline$\%$ RSU & Destinação \\
\hline 80,3 & Recolhido por caminhões e levado para lixões, aterros ou reciclagem \\
\hline 9,6 & Queimado na propriedade \\
\hline 7,2 & Disposto em caçamba \\
\hline 2,0 & Jogado em terreno baldio ou logradouro \\
\hline 0,6 & Enterrado na propriedade \\
\hline 0,2 & Outra destinação \\
\hline 0,1 & Jogado em rios, lagos ou mar \\
\hline
\end{tabular}

Como se sabe, muitos resíduos sólidos são abandonados em locais inadequados e proibidos, como em beiras de estradas e terrenos baldios. Exemplo disso é visto na Figura 1.

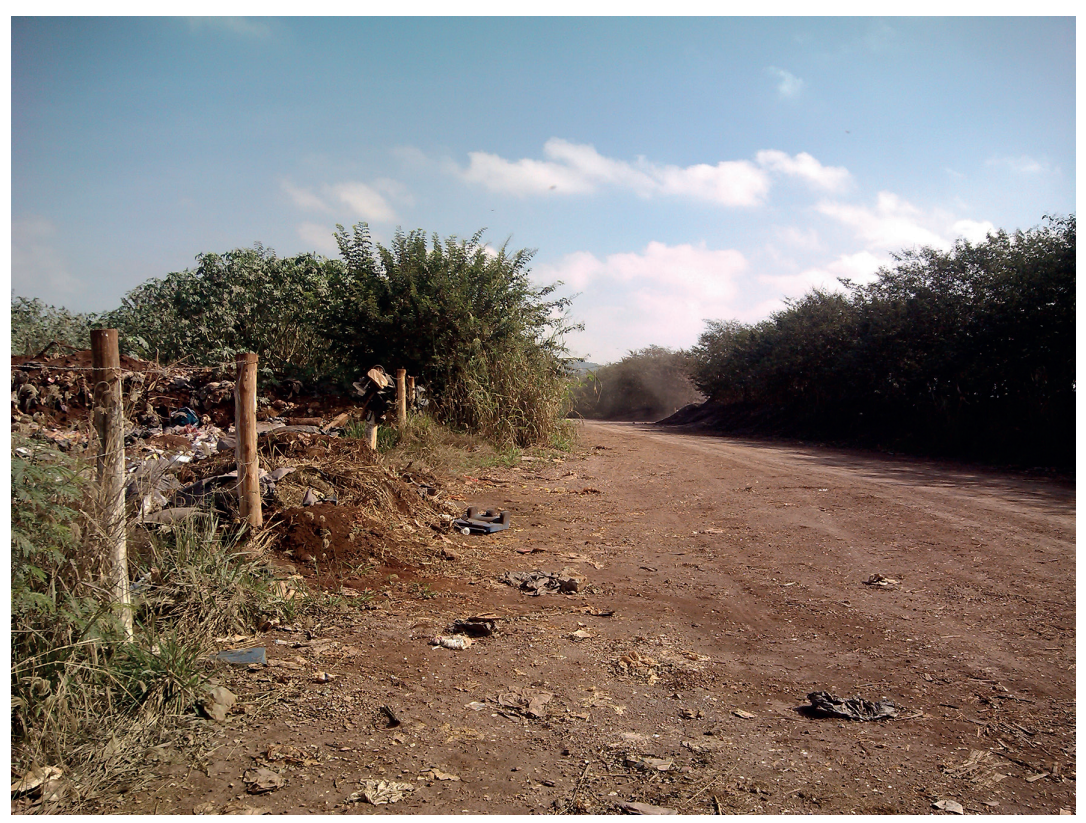

Figura 1. Lixo acumulado em estrada de terra, Limeira - SP. Autor: Gerusa Salado.

Abrelpe (2015) aponta que apenas cerca de 71 milhóes de toneladas de resíduos sólidos urbanos gerados no ano de 2014 foram coletados. Informa ademais que, além de aproximadamente 7,0 milhóes de toneladas de resíduos não terem sido coletadas, $41,6 \%$ do material que foi coletado - cerca de 30 
milhóes de toneladas - seguiram para lixóes e aterros controlados, trazendo consideráveis danos ao meio ambiente - Figura 2.

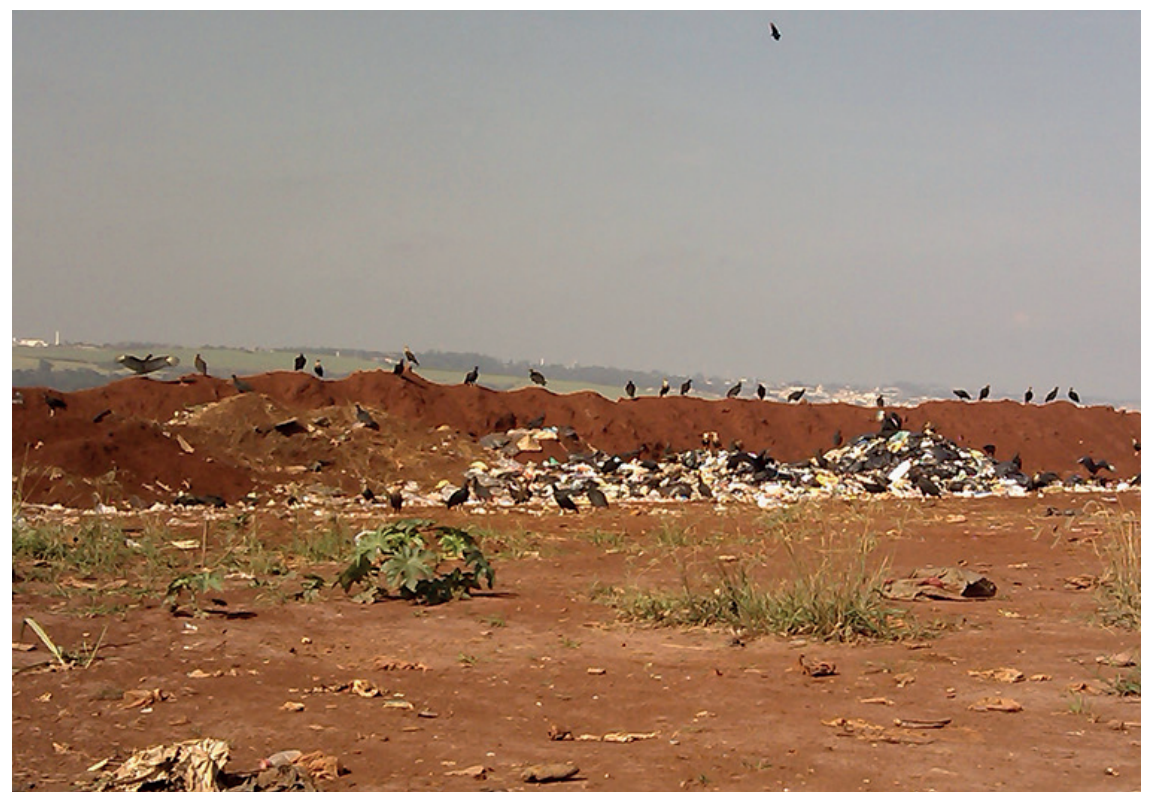

Figura 2. Lixo depositado a céu aberto em aterro controlado, Limeira - SP. Autor: Gerusa Salado.

Contudo, os resíduos sólidos gerados no Brasil e no mundo não são caracterizados apenas pelo lixo comumente oriundo de habitaçóes, escolas, hospitais, indústrias etc. A cadeia produtiva da construção civil, responsável por cerca de $8 \%$ do Produto Interno Bruto nacional, além de depender da extração de matérias-primas naturais, como a areia, a madeira, as pedras etc, produz imensos volumes de resíduos.

Segundo Sartor e Lamberts (2008), levantamentos indicaram que a construção e a manutenção de obras de edificaçôes em geral consomem até $75 \%$ dos recursos naturais extraídos no planeta. Concomitantemente, a ineficiência em alguns dos processos produtivos faz com que a indústria da construção civil seja reconhecidamente uma grande geradora de resíduos: quanto a isso, os levantamentos também mostraram que o lixo resultante da construção, manutenção e demolição de casas e edifícios representa de $40 \%$ a 60\% dos resíduos sólidos urbanos (SARTOR e LAMBERTS, 2008). 
O lixo produzido pela indústria da construção civil, portanto, representa um volume considerável. Apenas no ano de 2014 foram coletadas cerca de 45 milhôes de toneladas de resíduos de construção e demolição (RCD) no Brasil, ou seja, 4,1\% a mais que em 2013. Porém, sabe-se que as quantidades reais são ainda maiores, visto que os municípios em geral coletam somente os RCD depositados nos logradouros públicos (ABRELPE, 2015).

O maior problema com relação aos restos de materiais de construção gerados por pequenas reformas, construçóes e demoliçóes refere-se ao seu descarte, que quando feito de maneira inadequada, isto é, como se descarta o lixo comum, acaba gerando sérios danos para o meio ambiente. Geralmente, esses resíduos são jogados em terrenos baldios, beiras de estradas etc, como mostra a Figura 3.

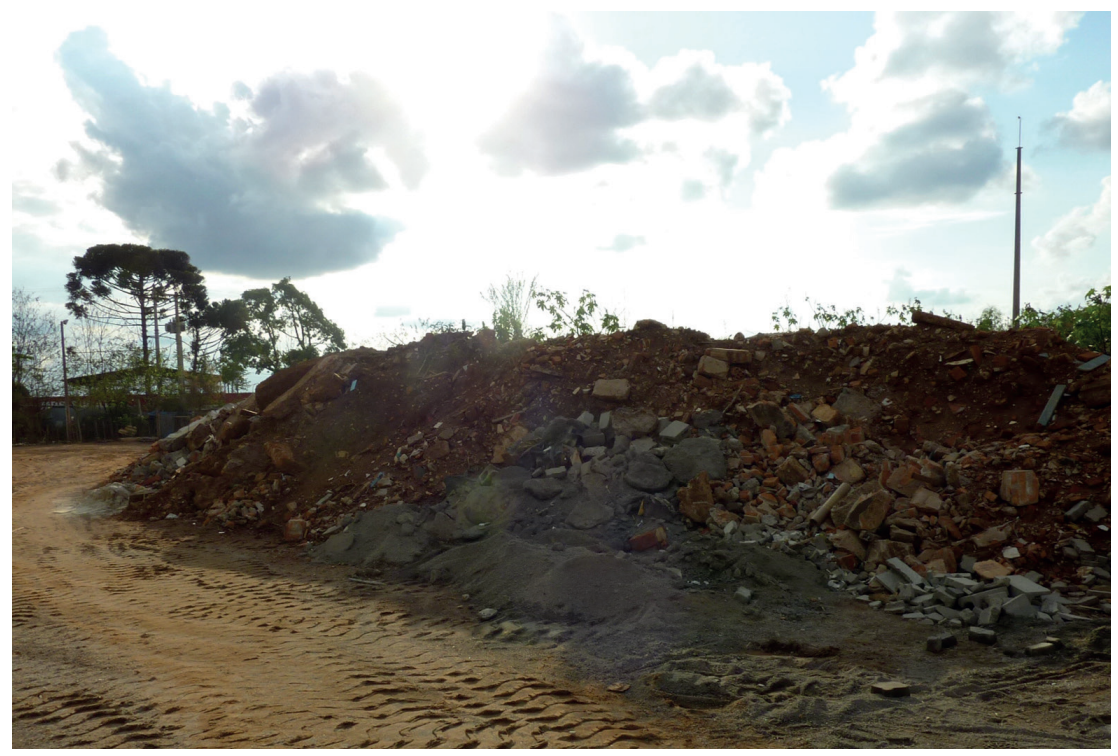

Figura 3. Entulho em São Carlos (SP), abandonado em área periférica da cidade. Autor: Gerusa Salado.

Além do volume acumulado nos depósitos e aterros sanitários, uma das maiores preocupaçóes com relação aos resíduos descartados inadequadamente diz respeito aos impactos que estes podem ter sobre a saúde humana e sobre o meio ambiente (solo, água e ar); sobretudo, os resíduos perigosos, produzidos em sua grande maioria pelas indústrias (KRAEMER, 2012a). 
A indústria necessita de matérias-primas, como o ferro, a água e a madeira, para a produção de bens necessários à sociedade. Por sua vez, os processos de manufatura produzem lixos, os quais podem ser inofensivos ou tóxicos.

O lixo gerado pelas atividades agrícolas e industriais é tecnicamente conhecido como resíduo. Rejeitos são os resíduos sólidos que, depois de esgotadas todas as possibilidades de tratamento e recuperação por processos tecnológicos disponíveis e economicamente viáveis, não apresentam outra possibilidade que não seja a disposição final ambientalmente adequada (KRAEMER, 2012a).

Seguindo o mesmo raciocínio, os residuos industriais são aqueles originados nas atividades dos diversos ramos da indústria, tais como: metalúrgico, químico, petroquímico, papelaria, indústria alimentícia etc. Esse tipo de lixoindustrial - é bastante variado e pode ser composto por cinzas, lodos, óleos, resíduos alcalinos ou ácidos, plásticos, papel, madeira, fibras, borracha, metal, escórias, vidros, cerâmicas etc. Nessa categoria, inclui-se grande quantidade de lixo tóxico, que necessita de tratamento especial pelo seu potencial de envenenamento.

O resíduo industrial é um dos maiores responsáveis pelas agressões fatais (acidentais ou não) ao meio ambiente. Nele, muitas vezes, estão incluídos produtos químicos (como cianureto, pesticidas e solventes), metais (como mercúrio, cádmio e chumbo) e solventes químicos que ameaçam os ciclos naturais nos quais são despejados. Quando descartados, os resíduos industriais sólidos são amontoados e enterrados, os líquidos são despejados em rios e mares e os gases são lançados no ar. Nessas condiçóes, a saúde do meio ambiente e dos seres vivos torna-se ameaçada, podendo ocorrer grandes tragédias ambientais.

Pode-se dizer que cerca de 10 a $20 \%$ dos resíduos industriais podem ser perigosos ao homem e ao ecossistema. Os metais pesados (elementos de elevado peso molecular), por exemplo, quando absorvidos pelo ser humano, depositam-se nos tecidos ósseo e gorduroso e deslocam minerais nobres dos ossos e músculos para a circulação, podendo provocar diversas doenças. Desse modo, o consumo habitual de água e alimentos como peixes de água doce ou do mar contaminados com metais pesados coloca em risco a saúde humana.

Da mesma forma, as populaçôes que moram em torno de fábricas de baterias artesanais, de indústrias de cloro-soda que utilizam mercúrio ou de 
indústrias navais, siderúrgicas e metalúrgicas também correm risco de serem contaminadas.

Os metais pesados são muito utilizados pelas indústrias e estão presentes na composição de vários produtos. A Tabela 2 apresenta os principais metais usados pelas indústrias, suas fontes e riscos à saúde humana.

Tabela 2 Principais metais usados pelas indústrias e seus riscos à saúde humana. Fonte: Kraemer, 2012a.

\begin{tabular}{|c|c|c|}
\hline Metais & De onde vem & Efeitos \\
\hline Alumínio & $\begin{array}{l}\text { Produção de artefatos de } \\
\text { alumínio; serralheria; soldagem } \\
\text { de medicamentos (antiácidos) e } \\
\text { tratamento convencional de água }\end{array}$ & $\begin{array}{l}\text { Anemia por deficiência de } \\
\text { ferro; intoxicação crônica }\end{array}$ \\
\hline Arsênio & $\begin{array}{l}\text { Metalurgia; manufatura de vidros e } \\
\text { fundição }\end{array}$ & Câncer (seios paranasais) \\
\hline Cádmio & Soldas; tabaco; baterias e pilhas & $\begin{array}{l}\text { Câncer de pulmões e próstata; } \\
\text { lesão nos rins }\end{array}$ \\
\hline Chumbo & $\begin{array}{l}\text { Fabricação e reciclagem de baterias } \\
\text { de autos; indústria de tintas; pintura } \\
\text { em cerâmica; soldagem }\end{array}$ & $\begin{array}{l}\text { Saturnismo (cólicas } \\
\text { abdominais, tremores, } \\
\text { fraqueza muscular, lesão renal } \\
\text { e cerebral) }\end{array}$ \\
\hline Cobalto & $\begin{array}{l}\text { Preparo de ferramentas de corte e } \\
\text { furadoras }\end{array}$ & $\begin{array}{l}\text { Fibrose pulmonar } \\
\text { (endurecimento do pulmão) } \\
\text { que pode levar à morte }\end{array}$ \\
\hline Cromo & $\begin{array}{l}\text { Indústrias de corantes, esmaltes, } \\
\text { tintas, ligas de aço e níquel, } \\
\text { cromagem de metais }\end{array}$ & Asma (bronquite); câncer \\
\hline $\begin{array}{l}\text { Fósforo } \\
\text { amarelo }\end{array}$ & $\begin{array}{l}\text { Veneno para baratas; rodenticidas } \\
\text { (tipo de inseticida usado na lavoura) } \\
\text { e fogos de artifício }\end{array}$ & $\begin{array}{l}\text { Náuseas; gastrite; odor } \\
\text { de alho; fezes e vômitos } \\
\text { fosforescentes; dor muscular; } \\
\text { torpor; choque; coma e até } \\
\text { morte }\end{array}$ \\
\hline Mercúrio & $\begin{array}{l}\text { Moldes industriais; certas indústrias } \\
\text { de cloro-soda; garimpo de ouro; } \\
\text { lâmpadas fluorescentes }\end{array}$ & $\begin{array}{l}\text { Intoxicação do sistema } \\
\text { nervoso central }\end{array}$ \\
\hline Níquel & $\begin{array}{l}\text { Baterias; aramados; fundição e } \\
\text { niquelagem de metais; refinarias }\end{array}$ & $\begin{array}{l}\text { Câncer de pulmão e seios } \\
\text { paranasais }\end{array}$ \\
\hline $\begin{array}{l}\text { Fumos } \\
\text { metálicos }\end{array}$ & $\begin{array}{l}\text { Vapores (de cobre, cádmio, } \\
\text { ferro, manganês, níquel e zinco) } \\
\text { da soldagem industrial ou da } \\
\text { galvanização de metais }\end{array}$ & $\begin{array}{l}\text { Febre dos fumos metálicos } \\
\text { (febre, tosse, cansaço e dores } \\
\text { musculares) - parecido com } \\
\text { pneumonia }\end{array}$ \\
\hline
\end{tabular}

Por outro lado, um resíduo não é, por definição, algo nocivo. Muitos resíduos podem ser transformados em subprodutos ou em matérias-primas 
para outras linhas de produção (KRAEMER, 2012a). A manipulação correta de um resíduo, entretanto, tem grande importância para o controle do risco que ele representa, pois um resíduo relativamente inofensivo, em mãos inexperientes, pode transformar-se em um risco ambiental muito grave.

Quanto aos resíduos sólidos industriais, conforme FIESP (2012a), não existem dados confiáveis sobre sua geração, tratamento e disposição final, o que inviabiliza investimentos, financiamentos e o desenvolvimento do setor.

Apesar dessa inexatidão, a FIESP (2012b) divulgou alguns dados referentes aos anos de 2006 e 2007, ressaltando, porém, que os números não refletem o total dos resíduos sólidos industriais (RSI) produzidos no período, visto que a responsabilidade pelo seu gerenciamento é do próprio gerador.

Dentro dessas condiçóes, portanto, foram levantadas as quantidades de RSI recebidos e tratados por empresas privadas no Brasil, de acordo com a tecnologia utilizada no processo de tratamento. A Tabela 3 expóe estas quantidades no período de 2006 e 2007 (FIESP, 2012b).

Tabela 3 Quantidades de resíduos sólidos industriais tratados em 2006 e 2007. Fonte: Pesquisas Abrelpe apud FIESP, $2012 \mathrm{~b}$.

\begin{tabular}{|c|c|c|}
\hline \multirow[t]{3}{*}{ Tecnologias } & \multicolumn{2}{|l|}{ RSI Tratados } \\
\hline & 2006 & 2007 \\
\hline & Quantidade (t/ano) & Quantidade (t/ano) \\
\hline Aterro para resíduos não inertes & 2.985 .521 & 3.655 .372 \\
\hline Aterro para resíduos inertes & 342.617 & 579.247 \\
\hline Aterro para resíduos perigosos & 170.776 & 251.646 \\
\hline $\begin{array}{l}\text { Coprocessamento em fornos de } \\
\text { cimento }\end{array}$ & 790.000 & 981.000 \\
\hline Incineração & 64.286 & 71.265 \\
\hline Outros tratamentos térmicos & 59.225 & 69.314 \\
\hline Tratamentos biológicos & 30.683 & 315.909 \\
\hline Outras tecnologias & 14.584 & 17.746 \\
\hline
\end{tabular}

A Figura 4 mostra o percentual das quantidades, em relação ao total de resíduos sólidos industriais tratados, em 2006 e 2007, respectivamente. 


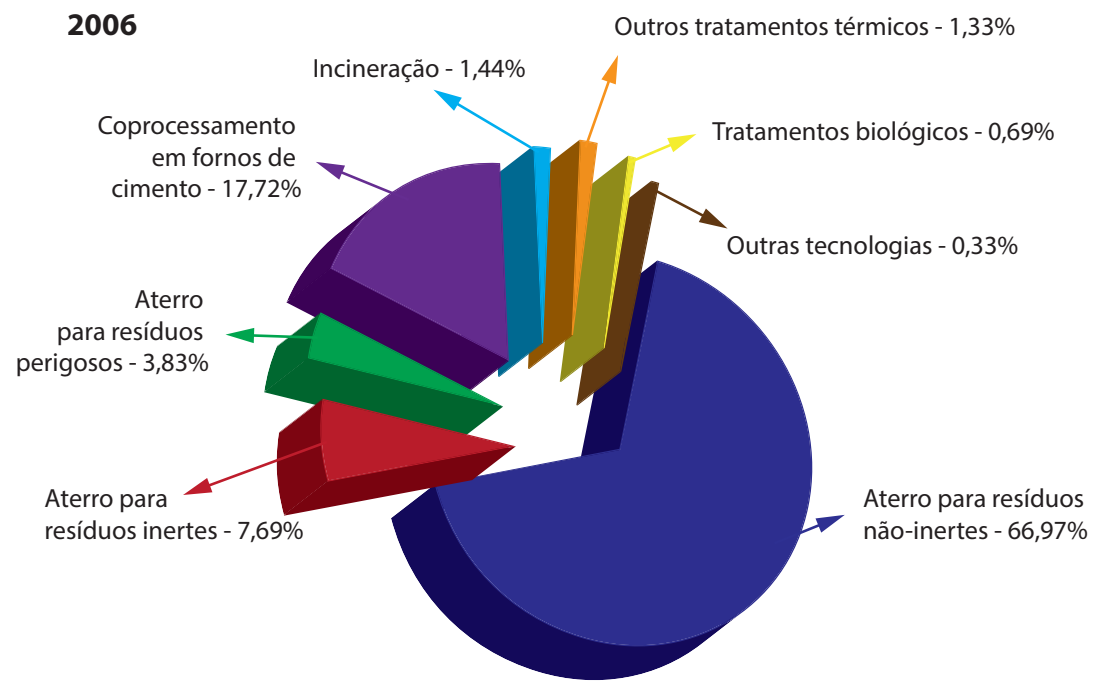

\section{7}

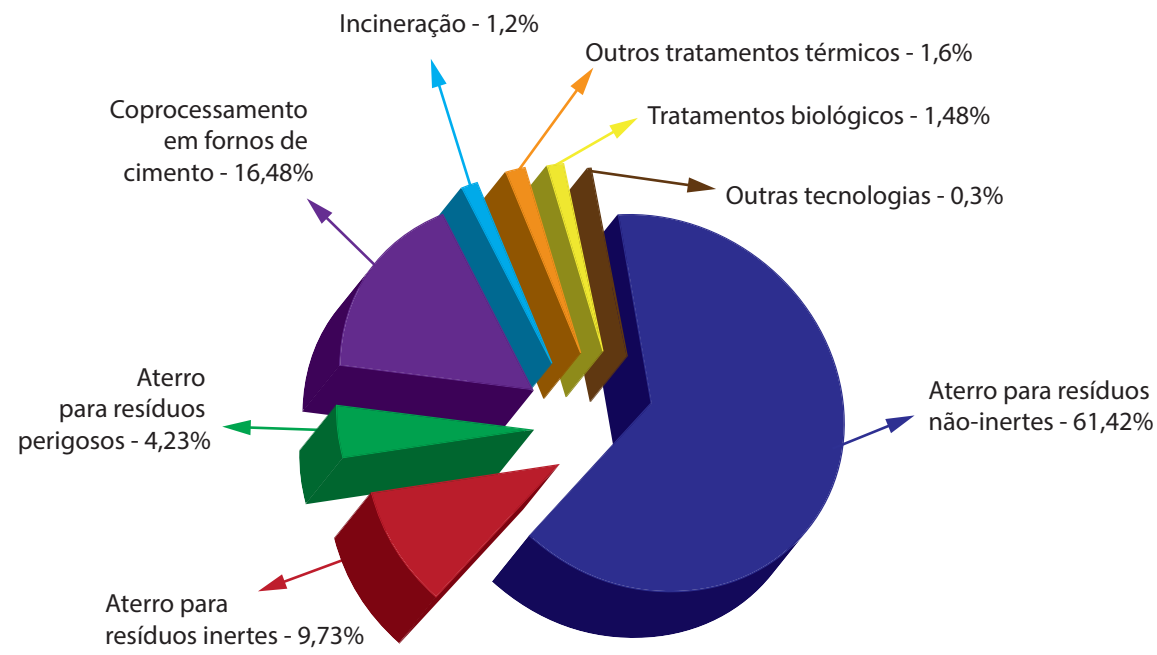

Figura 4. Percentuais de resíduos sólidos industriais tratados em 2006 e 2007. Fonte: Pesquisas Abrelpe apud FIESP, $2012 \mathrm{~b}$.

Considerando resíduos perigosos aqueles tratados pelas seguintes tecnologias: Aterro para Resíduos Perigosos, Coprocessamento em Fornos de Cimento, Incineração, Outros Tratamentos Térmicos, Tratamentos Biológicos e Outras Tecnologias, tem-se a Tabela 4. 
Tabela 4 Resíduos sólidos industriais perigosos e não perigosos tratados em 2006 e 2007. Fonte: Pesquisas Abrelpe apud FIESP, $2012 b$.

\begin{tabular}{lcrcr}
\hline Classificação & \multicolumn{2}{l}{$\mathbf{2 0 0 6}$} & \multicolumn{2}{c}{$\mathbf{2 0 0 7}$} \\
\cline { 2 - 5 } & Quantidade (t/ano) & \multicolumn{1}{l}{$\%$} & Quantidade (t/ano) & \multicolumn{1}{l}{$\%$} \\
\hline Perigosos & 1.009 .953 & 22,66 & 1.545 .360 & 26,00 \\
\hline Não perigosos & 3.447 .739 & 77,34 & 4.406 .139 & 74,03 \\
\hline Total & 4.457 .692 & 100,00 & 5.951 .499 & 100,00 \\
\hline
\end{tabular}

Nas indústrias, o tratamento dos resíduos constituintes de passivos ambientais teve crescimento. A Tabela 5 apresenta as quantidades dos resíduos industriais tratados em 2006 e 2007 em relação à origem dos resíduos.

Tabela 5 Resíduos sólidos industriais tratados em 2006 e 2007 em relação à sua origem. Fonte: Pesquisas Abrelpe apud FIESP, 2012b.

\begin{tabular}{lcccc}
\hline Origem & $\mathbf{2 0 0 6}$ & & $\mathbf{2 0 0 7}$ & \\
\cline { 2 - 5 } & $\begin{array}{l}\text { Quantidade } \\
\text { (t/ano) }\end{array}$ & \% & $\begin{array}{l}\text { Quantidade } \\
\text { (t/ano) }\end{array}$ & \% \\
\hline $\begin{array}{l}\text { Oriundos da geração normal } \\
\text { das indústrias }\end{array}$ & 3.689 .702 & 82,77 & 4.358 .232 & 72,23 \\
\hline $\begin{array}{l}\text { Oriundo de passivos ambientais } \\
\text { das indústrias }\end{array}$ & 767.990 & 17,23 & 1.593 .268 & 26,77 \\
\hline
\end{tabular}

Conforme relata outra fonte, a Agência Brasil (2009), o presidente da Associação Brasileira das Empresas de Tratamento de Resíduos (Abetre), Diógenes Del Bel, afirmou que no ano de 2008, as empresas que prestam serviço especializado e adequado para o setor de destinaçáo final de resíduos não aproveitáveis processaram mais de 7,0 milhóes de toneladas de resíduos industriais.

Os tratamentos empregados por essas empresas incluem o coprocessamento em fornos de produção de cimento, incineração, tratamentos biológicos para solos contaminados, descontaminação de transformadores e de lâmpadas, além das tecnologias que tratam da recuperação e reciclagem de óleos lubrificantes.

Segundo Del Bel apud Agência Brasil (2009), em 2009, o Brasil possuía 160 empresas para o tratamento de resíduos sólidos; um número pequeno em comparação a outros países, como o Reino Unido, por exemplo, onde já existiam cerca de 300 empresas somente para dar destinação final a resíduos eletroeletrônicos. 


\subsection{Política Nacional de Resíduos Sólidos}

A Lei no 12.305/10, que institui a Política Nacional de Resíduos Sólidos (PNRS), tem como objetivo combater os principais problemas ambientais, sociais e econômicos decorrentes do manejo inadequado dos resíduos sólidos no Brasil. Visa à prevenção e à redução na geração de resíduos, tendo como proposta a prática de hábitos de consumo sustentável e um conjunto de instrumentos para propiciar o aumento da reciclagem e da reutilização dos resíduos sólidos (aquilo que tem valor econômico e pode ser reciclado ou reaproveitado) e a destinação ambientalmente adequada dos rejeitos (aquilo que não pode ser reciclado ou reutilizado) (BRASIL, 2015).

Para isso, a lei institui a responsabilidade compartilhada dos geradores de resíduos: fabricantes, importadores, distribuidores, comerciantes, cidadáos e titulares de serviços de manejo dos resíduos sólidos urbanos na Logística Reversa dos resíduos e embalagens pós-consumo. Também institui instrumentos de planejamento nos níveis nacional, estadual, microrregional, intermunicipal, metropolitano e municipal e impóe que os particulares elaborem seus Planos de Gerenciamento de Resíduos Sólidos. Segundo Cempre (2013), a elaboração de planos municipais de gerenciamento de resíduos é condição legal para o acesso à recursos públicos federais, como os que se destinam à estrutura de coleta e construção de aterros sanitários.

Nas indústrias, a gestão dos resíduos já tem se incorporado ao planejamento e à visão de "cadeia de valor". Ao reduzir o uso de insumos extraídos da natureza com risco de impactos ambientais, evitar danos à biodiversidade, economizar energia e diminuir emissóes de gases de efeito estufa, a reciclagem representa uma vantagem competitiva para as indústrias. Apesar disso, em 2013, apenas $14 \%$ dos municípios brasileiros ofereciam coleta seletiva; sendo, destes, $86 \%$ situados no Sul e Sudeste do país.

Pode-se dizer que a PNRS incentiva a ação de catadores de materiais recicláveis e reutilizáveis, tanto na Logística Reversa quanto na Coleta Seletiva e objetiva contribuir para a eliminação dos lixôes. Além dos ganhos ambientais e sociais, com o avanço da logística reversa, o crescimento da oferta pode reduzir o preço dos materiais recicláveis, considerando os ganhos econômicos com a substituição de matéria-prima virgem por reciclada, emissóes de carbono, energia e impactos à biodiversidade. 


\section{Classificação e Tratamento de Resíduos Segundo as Normas Brasileiras}

Segundo Kraemer (2012a), desde os anos 50, os resíduos químicos e tóxicos vêm causando desastres cada vez mais frequentes e sérios. As indústrias eliminam resíduos por vários processos, nos estados gasoso, líquido e sólido. Geralmente, os resíduos sólidos são amontoados e enterrados, enquanto que os resíduos líquidos são despejados nos rios e mares, e os resíduos gasosos são lançados no ar. Assim, ocorre a poluição e contaminação do solo, da água e do ar.

Justamente por serem tão danosos, alguns resíduos perigosos são descartados aleatoriamente ou jogados no meio ambiente, pois não se sabe como lidar com eles com segurança e espera-se que o ambiente absorva as substâncias tóxicas. Porém, essa não é a solução correta para o problema, já que muitos metais e produtos químicos não são naturais, nem biodegradáveis.

Consequentemente, quanto mais se enterram os resíduos, ou os lançam na água e no ar, mais os ciclos naturais são ameaçados e o ambiente tornase poluído. Segundo Kraemer (2012a), atualmente existem mais de 7,0 milhôes de produtos químicos identificados e a cada ano outros milhares são descobertos, o que dificulta cada vez mais o tratamento efetivo dos resíduos.

Para evitar a poluição do meio ambiente e a contaminação dos seres vivos, as indústrias não podem despejar seus dejetos no lixo comum sem passar por tratamentos e cuidados especiais (CIMM, 2010). No Brasil, quem define os parâmetros para tratamento desses resíduos é a Associação Brasileira de Normas Técnicas (ABNT).

Desse modo, a NBR 10004 - Resíduos sólidos - Classificação (ABNT, 2004a) classifica os resíduos sólidos quanto aos seus riscos potenciais ao meio ambiente e à saúde pública, para que possam ser gerenciados adequadamente.

Essa classificação envolve a identificação do processo ou atividade que originou os resíduos sólidos, a identificação e características dos seus componentes, além da comparação desses componentes com listagens de resíduos e substâncias cujo impacto à saúde e ao meio ambiente é conhecido (ABNT, 2004a).

A NBR 10004 - Resíduos sólidos - Classificação - divide os resíduos conforme as reaçóes que produzem quando são colocados em contato com o meio ambiente e os classifica em dois grupos:

- perigosos (Classe I- contaminantes e tóxicos);

- não perigosos (Classe II - podem ou não ser contaminantes). 
Os resíduos Classe II são divididos em:

- náo-inertes (Classe II A - possivelmente contaminantes);

- inertes (Classe II B - não contaminantes).

Desses grupos, os resíduos das classes I e II A exigem atenção especial por serem tóxicos e/ou contaminantes.

Os resíduos das classes I e II devem ser tratados e destinados em instalaçóes apropriadas para tal fim. Por exemplo, os aterros industriais precisam de mantas impermeáveis e diversas camadas de proteção para evitar a contaminação do solo e das águas, além de instalações preparadas para receber o lixo industrial, normalmente operado por empresas privadas (KRAEMER, 2012b).

Para as atividades de gerenciamento de resíduos, a NBR 10004 - Resíduos sólidos - Classificação - é uma ferramenta imprescindível, sendo aplicada por instituiçôes e órgãos fiscalizadores. A partir da classificação estipulada pelo documento, o responsável por gerar um resíduo pode facilmente identificar o potencial de risco do material, bem como identificar as melhores alternativas para destinação final e/ou reciclagem.

Abaixo segue uma descrição detalhada das três classes compreendidas nessa norma técnica:

- Classe I - Resíduos perigosos: são aqueles que apresentam riscos significativos à saúde pública e ao meio ambiente, quando gerenciados de forma inadequada. Exigem tratamento e disposição especiais em função de suas características de inflamabilidade, corrosividade, reatividade, toxicidade e patogenicidade. Podem ocasionar a incidência ou o agravamento de doenças e mortalidade.

- Classe II A - Resíduos não-inertes: são os resíduos que não apresentam periculosidade, porém não são inertes; podem ter propriedades tais como: combustibilidade, biodegradabilidade ou solubilidade em água, tornando-a não potável. São, basicamente, os resíduos com as características do lixo doméstico.

- Classe II B - Resíduos inertes: são aqueles que, ao serem submetidos a testes de solubilização, não têm nenhum de seus constituintes solubilizados em concentraçôes superiores aos padróes de potabilidade da água. Isso significa que a água permanecerá potável quando em contato com o resíduo. Esses resíduos não se degradam ou não se decompõem quando dispostos no solo (se degradam muito lentamente) e muitos deles sáo recicláveis. Estão nessa classificação, por exemplo, os entulhos de demolição, pedras e areias retirados de escavaçóes. 
A Tabela 6 mostra as origens e as possíveis classes dos diferentes resíduos, bem como os agentes responsáveis pelo seu gerenciamento e destinação final adequada.

Tabela 6 Origens, possíveis classes e agentes responsáveis pelo gerenciamento dos resíduos. Fonte: Adaptado de Kraemer, 2012b.

\begin{tabular}{lll}
\hline Origem & Possíveis Classes & Responsável \\
\hline Domiciliar & II A & Prefeitura \\
\hline Comercial & II A, II B & Prefeitura \\
\hline Industrial & I, II A, II B & Gerador do resíduo \\
\hline Público & II A, II B & Prefeitura \\
\hline Serviços de Saúde & I, II A, II B & Gerador do resíduo \\
\hline $\begin{array}{l}\text { Portos, aeroportos e terminais } \\
\text { ferroviários }\end{array}$ & I, II A, II B & Gerador do resíduo \\
\hline Agrícola & & \\
\hline Entulho & I, II A, II B & Gerador do resíduo \\
\hline
\end{tabular}

Para ser possível classificar os resíduos deve-se, inicialmente, realizar ensaios de lixiviação e solubilização em amostras, seguindo as normas técnicas NBR 10005 - Procedimento para obtenção de extrato lixiviado de resíduos sólidos (ABNT, 2004b) e NBR 10006 - Procedimento para obtenção de extrato solubilizado de resíduos sólidos (ABNT, 2004c).

Os componentes encontrados nos ensaios devem ser comparados às tabelas anexas à NBR 10004 - Resíduos sólidos - Classificação - as quais determinam a existência de periculosidade e as características (inflamabilidade, corrosividade, toxicidade, reatividade e patogenicidade) do resíduo.

Dessa maneira, caso um resíduo seja classificado como classe I, ele não poderá ser incorporado a outros produtos, devido aos riscos que oferece à saúde dos seres vivos e ao meio ambiente, e deverá receber tratamento especial e adequado de empresas especializadas.

Quando um resíduo for classificado como classe II A, ele poderá ser incorporado a outros produtos com certas restriçóes e de maneira adequada, conforme o grau e características contaminantes que apresenta.

Por fim, quando um resíduo for classificado como classe II B, ele poderá ser incorporado em outros produtos sem restriçôes.

O fluxograma apresentado na Figura 5 mostra os passos que devem ser seguidos para a classificação de um resíduo. 


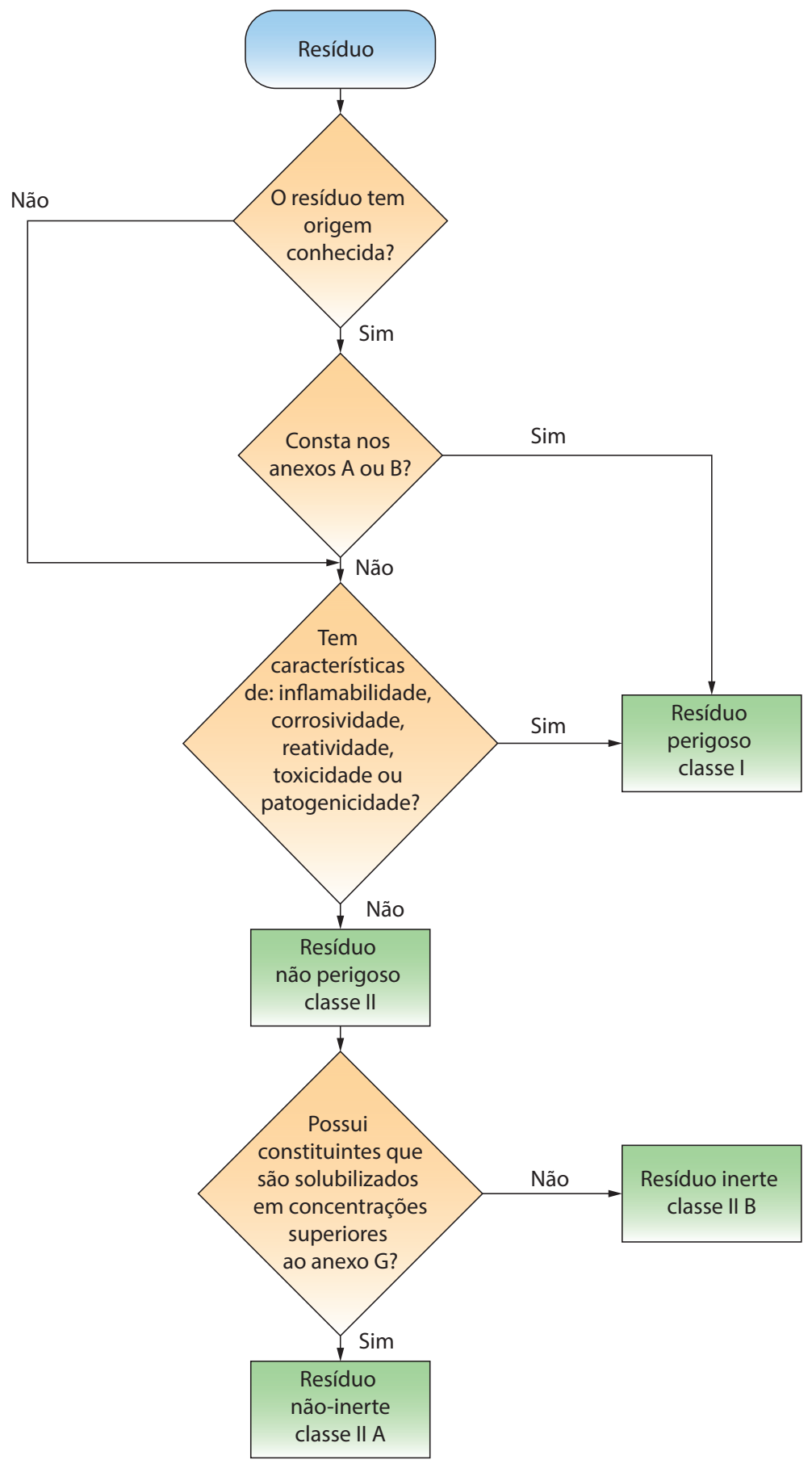

Figura 5. Caracterização e classificação de resíduos sólidos. Fonte: ABNT, 2004a, p.vi. 


\subsection{Resolução no 307 - CONAMA}

O Conselho Nacional do Meio Ambiente - CONAMA publicou a Resolução no 307 em 2002, para estabelecer diretrizes, critérios e procedimentos para a gestão dos resíduos da construção civil, disciplinando as ações necessárias de forma a minimizar os impactos ambientais.

De acordo com a resolução, os responsáveis pela produção de resíduos da construção civil devem ser responsáveis pelos restos das atividades de construção, reforma, reparos e demolições de estruturas e estradas, bem como pelas sobras resultantes da remoção de vegetação e escavação de solos.

Os resíduos da construção civil, por sua vez, deverão ser discriminados conforme a seguinte classificação:

- Classe A - são os resíduos reutilizáveis ou recicláveis como agregados, tais como:

a) de construção, demolição, reformas e reparos de pavimentação e de outras obras de infraestrutura, inclusive solos provenientes de terraplanagem;

b) de construçấo, demolição, reformas e reparos de edificaçóes: componentes cerâmicos (tijolos, blocos, telhas, placas de revestimento etc), argamassa e concreto;

c) de processo de fabricação e/ou demolição de peças pré-moldadas em concreto (blocos, tubos, meios-fios etc) produzidas nos canteiros de obras;

- Classe B - sáo os resíduos recicláveis para outras destinaçóes, tais como: plásticos, papel, papelão, metais, vidros, madeiras e gesso;

- Classe C - são os resíduos para os quais não foram desenvolvidas tecnologias ou aplicaçóes economicamente viáveis, as quais permitem a sua reciclagem ou recuperação;

- Classe D - são resíduos perigosos, oriundos do processo de construção, tais como tintas, solventes, óleos, bem como aqueles contaminados ou prejudiciais à saúde, provenientes de demoliçóes, reformas e reparos de clínicas radiológicas, instalaçôes industriais e outros. Além de telhas e demais objetos que contenham amianto ou outros produtos nocivos à saúde.

A resolução determina que os resíduos da construção civil não podem ser dispostos em aterros de resíduos sólidos urbanos, em áreas de "bota fora", em encostas, corpos d'água, lotes vagos e em áreas protegidas por Lei, devendo ser adequadamente destinados como pode ser visto logo abaixo. 
Quanto aos Planos de Gerenciamento de Resíduos da Construção Civil, estes devem contemplar as seguintes etapas:

I - caracterização: nesta etapa o gerador deve identificar e quantificar os resíduos;

II - triagem: deve ser realizada preferencialmente pelo gerador na origem ou ser realizada nas áreas de destinaçáo licenciadas para essa finalidade, respeitadas as classes de resíduos;

III - acondicionamento: o gerador deve garantir o confinamento dos resíduos após a geração até a etapa de transporte, assegurando, em todos os casos em que sejam possíveis, as condiçóes de reutilização e de reciclagem;

IV - transporte: deve ser realizado em conformidade com as etapas anteriores e de acordo com as normas técnicas vigentes para o transporte de resíduos;

V - destinação: deve ser prevista de acordo com o estabelecido na resolução.

Após triagem, os resíduos da construção civil devem ser destinados das seguintes formas:

I Classe A - devem ser reutilizados ou reciclados na forma de agregados ou encaminhados a aterro de resíduos classe A de reservaçáo de material para usos futuros;

II Classe B - devem ser reutilizados, reciclados ou encaminhados a áreas de armazenamento temporário, sendo dispostos de modo a permitir a sua utilização ou reciclagem futura;

III Classe C - devem ser armazenados, transportados e destinados em conformidade com as normas técnicas específicas.

IV Classe D - devem ser armazenados, transportados e destinados em conformidade com as normas técnicas específicas.

Por fim, a resolução afirma que o Plano Municipal de Gestão de Resíduos da Construção Civil, a ser elaborado pelos Municípios e pelo Distrito Federal, em consonância com o Plano Municipal de Gestão Integrada de Resíduos Sólidos, deve servir como um instrumento para a implementação da gestão dos resíduos da construção civil. 


\section{Propostas de Metodologias para Avaliação da Estabilização/Solidificação (Encapsulação) de Resíduos Industriais para Uso em Matrizes Cimentícias, Poliméricas e Cerâmicas e para Desenvolvimento de Produtos para a Construção Civil}

A solidificação/estabilização de resíduos sólidos é um processo também conhecido por encapsulação ou fixação. Trata-se de uma tecnologia alternativa aos processos tradicionais de tratamento de resíduos e serve, principalmente, como um meio de facilitar o manuseio, o transporte e o armazenamento de resíduos. Em síntese, consiste em estabilizar química e/ou fisicamente os resíduos sólidos através da adição de aglomerantes ou da inserção em invólucros eficientes (PABLOS, 2008).

De acordo com Cláudio (1987), o termo encapsulação significa o processo usado para fixar, imobilizar ou restringir a capacidade de solubilização de um resíduo, reduzindo a sua toxicidade ao meio ambiente. Conforme Poon et al. (1986) esse processo é um pré-tratamento que induz reaçóes químicas e mecanismos físicos para fixarem elementos ou compostos tóxicos em polímeros impermeáveis ou em cristais estáveis.

Estabilização remete às técnicas de minimizar as periculosidades potenciais de um resíduo, reduzindo ao máximo a solubilidade, mobilidade e toxicidade dos contaminantes sem, necessariamente, alterar a natureza física do resíduo.

Solidificação, por sua vez, está relacionada às técnicas de encapsulação do resíduo em um sólido monolítico com elevada integridade estrutural. $\mathrm{O}$ processo nem sempre envolve algum tipo de interação química entre os resíduos e os reagentes dos materiais aglomerantes adotados, mas deve blindar mecanicamente o resíduo dentro de uma estrutura sólida. Assim sendo, a mobilidade dos contaminantes se torna difícil, devido à escassez de área superficial exposta à lixiviação e pelo fato de os resíduos estarem isolados em cápsulas impermeáveis (CONNER e HOEFFNER, 1998).

\subsection{Técnicas Desenvolvidas}

Conforme Pablos (2008), existem diversas técnicas de estabilização/ solidificação de resíduos sólidos. As principais técnicas são: à base de cimento, 
à base de cal e materiais pozolânicos (exceto cimento), à base de polímeros orgânicos, à base de argilas, vitrificação, encapsulação em invólucro inerte e auto-solidificação.

A seguir, essas técnicas são apresentadas de forma resumida.

\subsubsection{Técnica à Base de Materiais Pozolânicos}

Pozolanas são materiais naturais ou artificiais que contém sílica ativa, formando silicatos de cálcio com propriedades aglomerantes na presença de água. Geralmente, os materiais pozolânicos usados no tratamento de resíduos são as cinzas volantes, poeiras de forno de cimento e escória de alto-forno, xistos calcinados, telhas e tijolos cerâmicos moídos, pedra-pomes e cinzas de carvão oriundas de termo-elétricas.

As principais vantagens dessa técnica são o baixo custo dos materiais empregados, disponíveis em grande escala, a falta de necessidade de equipamentos especiais no processo, e o conhecimento das reaçôes envolvidas.

Contudo, existem algumas desvantagens, como a lentidão das reações e a baixa resistência mecânica do material solidificado.

\subsubsection{Técnica à Base de Polímeros Orgânicos}

A técnica de solidificação/estabilização bastante utilizada com polímeros orgânicos chama-se ureia-formaldeído. No processo, o resíduo é misturado com um pré-polímero e com catalisador (CETESB, 1985).

Normalmente, o material polimerizado não se mistura quimicamente com o resíduo, mas forma uma massa esponjosa que captura as partículas sólidas. Com isso, existe o risco de contaminantes serem liberados caso o polímero se degrade ou se rompa. A reação de polimerização, além disso, libera gases tóxicos que exigem cuidados especiais durante a operação.

Em contrapartida, o material solidificado possui volume pequeno e massa específica baixa, em relação a outros processos, e a quantidade necessária de material solidificante é pequena (CLÁUDIO, 1987).

\subsubsection{Técnica de Encapsulação em Invólucro Inerte}

No processo de encapsulação em invólucro inerte, o resíduo é inicialmente prensado ou aglomerado e, posteriormente, envolvido por uma jaqueta ou 
camisa de material inerte. Geralmente, esse material de revestimento é o polietileno, o qual está sujeito a danos quando exposto a temperaturas elevadas e raios ultravioletas.

A técnica garante segurança total contra lixiviação e solubilização de poluentes; porém, seu custo é alto em virtude da necessidade de equipamentos sofisticados e mão de obra especializada (CETESB, 1985).

\subsubsection{Técnica de Vitrificação}

$\mathrm{Na}$ tentativa de formar um vidro ou um mineral de silicato sintético, alguns experimentos são feitos combinando resíduos com sílica e fundindo a mistura.

Como o vidro e os silicatos cristalinos são lixiviados muito lentamente pela água, esse processo é considerado seguro no que diz respeito à disposição final de resíduos. Entretanto, são necessárias instalações semelhantes à de uma indústria de vidros para fazê-lo e consumo energético intensivo acima de $1350^{\circ} \mathrm{C}$ para que a mistura resíduo-silicato seja fundida (CETESB, 1985).

\subsubsection{Técnica de Auto Solidificação}

Resíduos industriais como lodos de limpeza de exaustão ou dessulfurização contêm grandes quantidades de sulfeto ou sulfato de cálcio, e quando calcinados apresentam propriedades aglomerantes.

Neste caso, a autossolidificação é possível, calcinando-se uma pequena porção do lodo (em torno de 8 a 10\% do total) sob condições cuidadosamente controladas para produzir o aglomerante. $\mathrm{O}$ resíduo calcinado é misturado ao restante do lodo, juntamente com alguns aditivos, promovendo uma solidificação geral.

O material resultante é muito resistente, de baixa permeabilidade e com boa retençáo de metais pesados presentes no resíduo. As desvantagens dessa técnica consistem na necessidade de equipamentos especiais e de energia adicional para gerar a calcinação (CETESB, 1985).

\subsubsection{Técnica à Base de Argilas}

As argilas bentonitas são as mais utilizadas nessa técnica. Dessa forma, as argilas bentonitas sódicas quando adicionadas de sais quaternários de amônia são transformadas em argilas organofílicas que, por sua vez, são 
associadas ao cimento para que interajam com os compostos orgânicos dos resíduos, garantam sua fixação através da troca da amônia pelos compostos orgânicos e os impeçam de interferir no processo de hidratação do cimento (WARREN et al., 1986).

\subsubsection{Técnica à Base de Cimento Portland}

Em se tratando de estabilização/solidificação de resíduos, o termo matriz significa a estrutura básica na qual os resíduos são fixados química e/ou fisicamente. Devido à simplicidade do processo e ao baixo custo, a fixação de resíduos perigosos em matrizes de cimento Portland é a técnica de estabilização/solidificação mais empregada. Essa técnica é especialmente indicada para resíduos metálicos (DANIALI, 1990).

A Tabela 7 mostra a compatibilidade de alguns resíduos com o processo de estabilização/solidificação em cimento.

Tabela 7 Exemplos de aplicação da técnica de estabilização/solidificação em matrizes de cimento. Fonte: Saito et. al, 1985, apud Hanna, 1996.

\begin{tabular}{lll}
\hline Indústria/Atividade & Tipo de Resíduo & Poluente \\
\hline Galvanoplastia & Torta, lama & $\mathrm{Cr}, \mathrm{Pb}, \mathrm{Cu}, \mathrm{Ni}, \mathrm{Zn}$ \\
\hline Galvanoplastia & Torta, lama & $\mathrm{Zn}$ \\
\hline Componentes eletrônicos & Torta, lama & $\mathrm{C}, \mathrm{Sn}, \mathrm{Pb}$ \\
\hline Químicos orgânicos & Líquido & $\mathrm{Pb}, \mathrm{Ti}$ \\
\hline Lavagem de gases & Líquido & $\mathrm{Sulfatos}$ alcalinos \\
\hline Catálise petroquímica & Sólido & $\mathrm{Co}, \mathrm{Mo}, \mathrm{Ni}$ \\
\hline Tratamentos metálicos & Líquido & $\mathrm{Zn}, \mathrm{Mg}, \mathrm{Ba}$ ácidos \\
\hline Farmacêutica & Torta, lama & $\mathrm{Zn}, \mathrm{Hg}, \mathrm{Ba}, \mathrm{Be}$ \\
\hline Acabamento metálico & Sólido & $\mathrm{Cu}, \mathrm{Ni}, \mathrm{Zn}$ \\
\hline Incineração & Torta, lama & $\mathrm{Mn}, \mathrm{Fe}, \mathrm{Pb}, \mathrm{Zn}, \mathrm{V}$ \\
\hline Decapagem ácida & Torta, lama & $\mathrm{Cr}, \mathrm{Zn}, \mathrm{Fe}$, ácidos \\
\hline Acabamento de $\mathrm{Al}$ & Torta, lama & $\mathrm{Cr}, \mathrm{Cu}$, ácidos \\
\hline
\end{tabular}

Segundo Pablos (2008), como os metais não podem ser destruídos por incineração, as alternativas de tratamentos para resíduos contendo metais tornamse limitadas. Por isso, a técnica de estabilização/solidificação é considerada a melhor forma de disposição viável atualmente para esse tipo de resíduo. 
De acordo com Mackay e Emery (1992), durante a hidratação do cimento são formados de 20 a 30\% de hidróxido de cálcio, formando uma solução sólida nos poros com pH em torno de 12 a 13. Esse meio alcalino favorece a formação de compostos insolúveis, como hidróxidos e silicatos de metálicos.

Conforme Pablos (2008), são várias as vantagens de se utilizar a técnica de estabilização/solidificação à base de cimento Portland:

- os custos referentes ao cimento Portland e aos equipamentos necessários são relativamente baratos e o consumo de energia é baixo;

- existe um conhecimento bastante difundido a respeito dessa tecnologia, do controle da mistura e de seu manuseio;

- não é necessário secar e desidratar o resíduo, uma vez que será adicionada uma quantia de água para a hidratação do cimento;

- a mistura tolera diversas variaçôes químicas, devido à alcalinidade do cimento, que propicia a neutralizaçáo de ácidos, e o protege da açáo de oxidantes fortes, como os nitratos;

- permite originar produtos finais com a resistência mecânica e a permeabilidade desejadas;

- com a aplicação de um revestimento selante é possível melhorar as questôes de lixiviaçáo e solubilizaçáo do produto final;

- é possível tratar os resíduos no próprio local onde foram indevidamente depositados.

Por outro lado, de acordo com CETESB (1985), existem algumas desvantagens para essa técnica:

- o grande consumo de cimento;

- a massa e o volume do produto final geralmente são o dobro em relação a outros processos de fixaçáo;

- a possibilidade da formação de amônia, devido à alcalinidade do cimento;

- a necessidade de aterros industriais para a disposição dos produtos finais não revestidos;

- a necessidade de um pré-tratamento com o uso de cimentos especiais e aditivos de custo elevado, quando os resíduos contêm grandes quantias de impurezas, as quais podem prejudicar o endurecimento e a cura da mistura resíduo-cimento, tais como boratos e sulfatos.

Com base nas informaçóes acima, elaborou-se a tabela a seguir, a fim de possibilitar uma breve comparação entre as diversas técnicas de estabilização/ solidificação de resíduos, no que diz respeito às suas vantagens e desvantagens. 
Tabela 8 Principais técnicas de estabilização/solidificação de resíduos.

\begin{tabular}{|c|c|c|}
\hline Técnicas & Vantagens & Desvantagens \\
\hline \multirow{4}{*}{$\begin{array}{l}\text { Materiais } \\
\text { pozolânicos }\end{array}$} & Baixo custo & Lentidão das reações \\
\hline & $\begin{array}{l}\text { Materiais disponíveis em grande } \\
\text { escala }\end{array}$ & \multirow[t]{3}{*}{$\begin{array}{l}\text { Material solidificado tem baixa } \\
\text { resistência mecânica }\end{array}$} \\
\hline & $\begin{array}{l}\text { Não necessita de equipamentos } \\
\text { especiais }\end{array}$ & \\
\hline & $\begin{array}{l}\text { Conhecimento das reações } \\
\text { ocasionadas }\end{array}$ & \\
\hline \multirow[t]{2}{*}{$\begin{array}{l}\text { Polímeros } \\
\text { orgânicos }\end{array}$} & $\begin{array}{l}\text { Material solidificado possui } \\
\text { volume pequeno e massa } \\
\text { específica baixa }\end{array}$ & $\begin{array}{l}\text { Risco de contaminantes serem } \\
\text { liberados caso o polímero se } \\
\text { degrade ou se rompa }\end{array}$ \\
\hline & $\begin{array}{l}\text { Quantidade necessária de } \\
\text { material solidificante é pequena }\end{array}$ & $\begin{array}{l}\text { Reação de polimerização libera } \\
\text { gases tóxicos }\end{array}$ \\
\hline \multirow[t]{3}{*}{$\begin{array}{l}\text { Encapsulação } \\
\text { em invólucro } \\
\text { inerte }\end{array}$} & \multirow[t]{3}{*}{$\begin{array}{l}\text { Segurança total contra lixiviação } \\
\text { e solubilização }\end{array}$} & $\begin{array}{l}\text { Necessidade de equipamentos } \\
\text { sofisticados e mão de obra } \\
\text { especializada }\end{array}$ \\
\hline & & Custo elevado \\
\hline & & $\begin{array}{l}\text { O material de revestimento, } \\
\text { geralmente o polietileno, } \\
\text { sofre danos em temperaturas } \\
\text { elevadas e raios ultravioleta }\end{array}$ \\
\hline \multirow[t]{3}{*}{ Vitrificação } & \multirow[t]{3}{*}{$\begin{array}{l}\text { Processo seguro (lixiviação } \\
\text { ocorre muito lentamente pela } \\
\text { água) }\end{array}$} & $\begin{array}{l}\text { Necessidade de instalações } \\
\text { semelhantes à de uma indústria } \\
\text { de vidros }\end{array}$ \\
\hline & & Consumo energético elevado \\
\hline & & Custo elevado \\
\hline \multirow[t]{3}{*}{$\begin{array}{l}\text { Auto- } \\
\text { solidificação }\end{array}$} & $\begin{array}{l}\text { Material resultante muito } \\
\text { resistente }\end{array}$ & $\begin{array}{l}\text { Necessidade de equipamentos } \\
\text { especiais }\end{array}$ \\
\hline & Baixa permeabilidade & \multirow[t]{2}{*}{ Consumo energético elevado } \\
\hline & Boa retenção de metais pesados & \\
\hline \multirow{8}{*}{$\begin{array}{l}\text { Cimento } \\
\text { Portland }\end{array}$} & Simplicidade do processo & \multirow{3}{*}{$\begin{array}{l}\text { Necessita de um revestimento } \\
\text { selante para melhorar as } \\
\text { questões de lixiviação e } \\
\text { solubilização do produto final }\end{array}$} \\
\hline & Baixo custo & \\
\hline & Baixo consumo energético & \\
\hline & Domínio da tecnologia & Consumo de cimento elevado \\
\hline & $\begin{array}{l}\text { Não é necessário secar e } \\
\text { desidratar o resíduo }\end{array}$ & $\begin{array}{l}\text { Produto final com grande } \\
\text { volume e massa específica alta }\end{array}$ \\
\hline & $\begin{array}{l}\text { Compatível a diversas variações } \\
\text { químicas }\end{array}$ & \multirow{3}{*}{$\begin{array}{l}\text { Pode gerar amônia } \\
\text { Necessidade de pré-tratamento } \\
\text { com o uso de cimentos } \\
\text { especiais e aditivos de custo } \\
\text { elevado, quando os resíduos } \\
\text { contém grandes quantias de } \\
\text { impurezas }\end{array}$} \\
\hline & $\begin{array}{l}\text { Origina produtos finais com } \\
\text { a resistência mecânica e a } \\
\text { permeabilidade desejadas }\end{array}$ & \\
\hline & $\begin{array}{l}\text { Possibilita tratar os resíduos } \\
\text { no próprio local onde foram } \\
\text { depositados }\end{array}$ & \\
\hline
\end{tabular}




\section{Proposição de Protocolo para Análise dos Impactos Ambientais e para a (re) Reutilização de Resíduos Gerados a Partir de Demolição de Sistemas Construtivos com Resíduos Industriais Incorporados}

Para analisar os possíveis impactos ambientais causados pelo descarte de resíduos de construção e demolição que contenham resíduos industriais incorporados é necessário realizar ensaios de lixiviação e solubilização em amostras desses materiais. Assim, os resultados dos ensaios indicarão, através da NBR 10004, se os resíduos apresentam periculosidade ou são contaminantes para o meio ambiente.

Da mesma maneira, para a (re) reutilização de resíduos gerados a partir da demolição de sistemas construtivos com resíduos industriais incorporados, a realização dos ensaios de lixiviação e solubilização se faz obrigatória, assim como a classificação destes resíduos usando-se a NBR 10004.

Isso quer dizer que sempre, para que resíduos industriais sejam incorporados em materiais ou componentes para a construção civil, ou que resíduos de construção e demolição que contenham resíduos industriais incorporados sejam reutilizados, deve-se seguir o seguinte protocolo:

- realizar ensaios de lixiviaçáo e solubilizaçáo em amostras dos resíduos, segundo a NBR 10005 e a NBR 10006;

- classificar os resíduos segundo a NBR 10004;

- eleger uma técnica de estabilização/solidificação para reutilizar esses resíduos;

- realizar ensaios de lixiviação e solubilização em amostras do produto gerado, segundo a NBR 10005 e a NBR 10006, para checar a estabilização dos resíduos incorporados.

Devido à possibilidade de os resíduos industriais serem perigosos ou contaminantes, torna-se extremamente importante a fiscalização do processo de reutilização destes na construção civil; o que deve ser feito apenas em usinas de reciclagem de materiais de construção, como se mostra na Figura 6, ou em indústrias devidamente capacitadas e segundo os procedimentos descritos acima, fazendo-se sempre os ensaios de lixiviação e solubilização nos resíduos, para a sua correta classificação e forma de reutilização. 

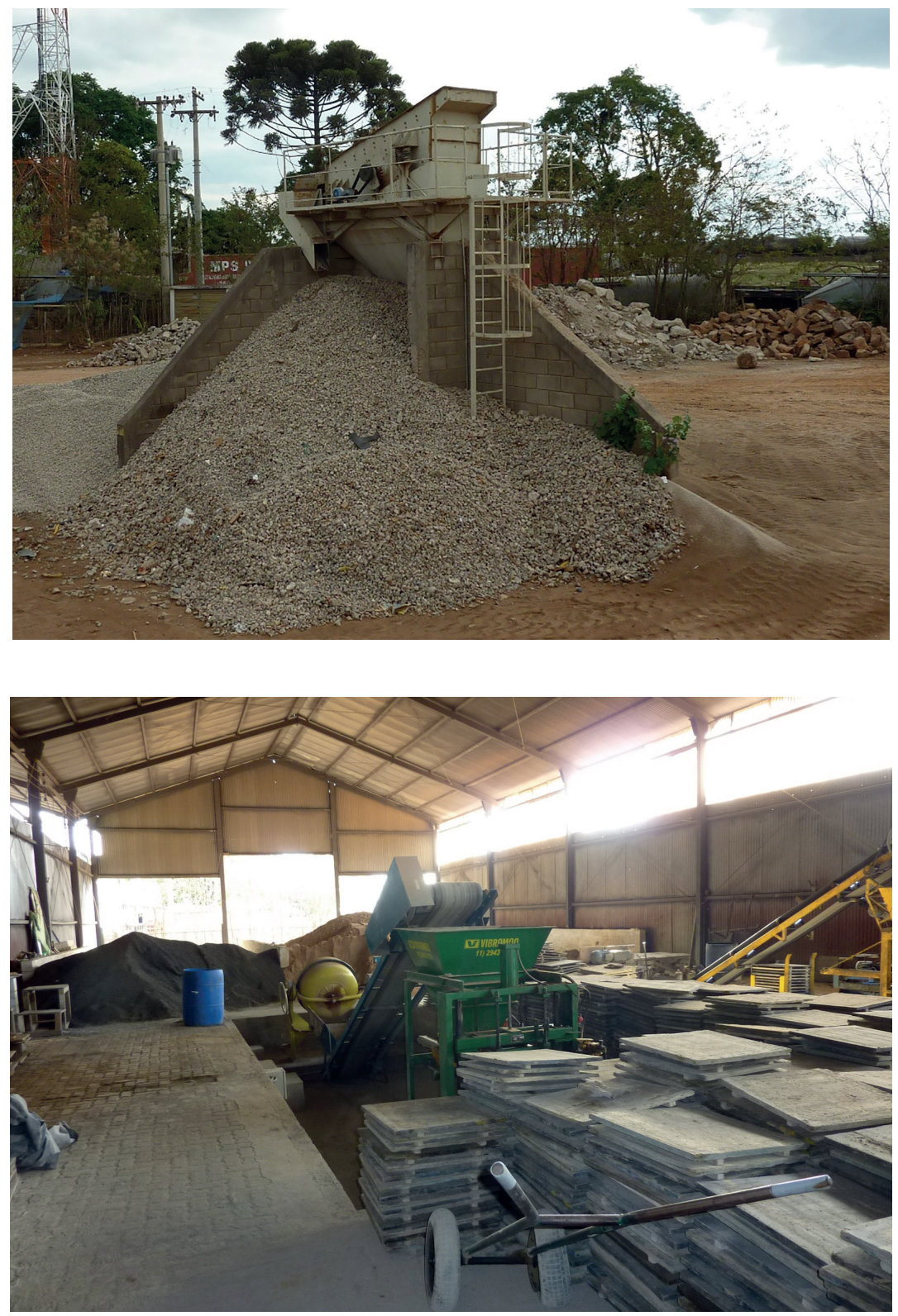

Figura 6. Usina de reciclagem de materiais de construção em São Carlos - SP. Autor: Gerusa Salado.

Os resíduos da construção e demolição devem ser separados por tipo (madeira, concreto, aço, vidro etc) e destinados à devida reutilização ou reciclagem, podendo gerar diversos novos elementos - Figura 7. 

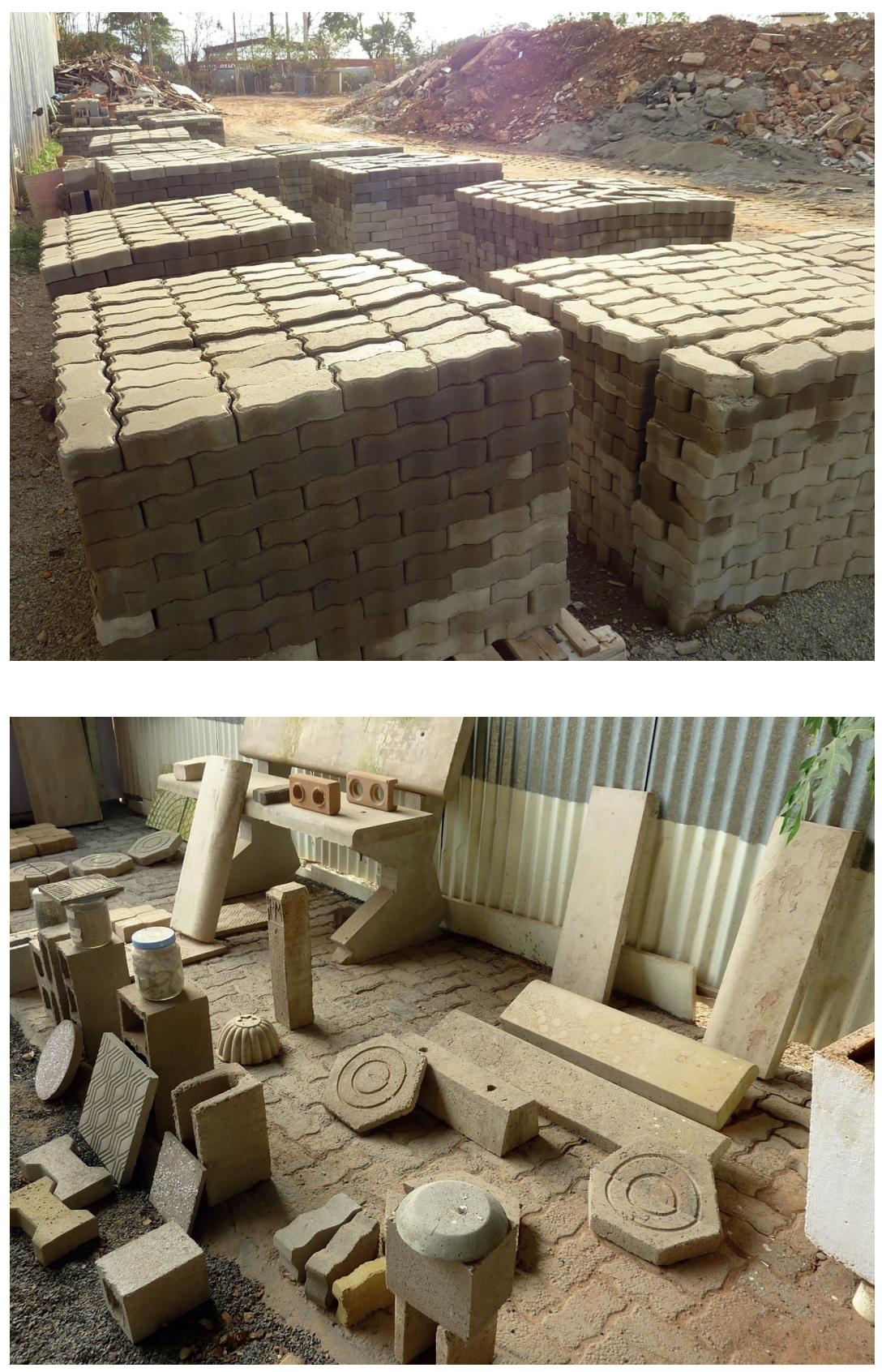

Figura 7. Elementos produzidos em usina de reciclagem de materiais de construção em São Carlos - SP. Autor: Gerusa Salado. 
Após a etapa de classificação, os resíduos podem ser reincorporados em materiais e componentes para a construção civil quantas vezes se desejar, desde que sempre seguindo os procedimentos e ensaios descritos acima.

\section{Conclusões}

Cada brasileiro gera, em média, 1,0 kg de resíduo por dia: mais que um africano, menos que um europeu. Isso mostra que quanto maior a renda de um país, maiores são o consumo e a quantidade de resíduos que precisa de soluçáo para voltar ao mercado e não impactar negativamente o meio ambiente.

Com o desenvolvimento econômico, a tendência é o padrão brasileiro se aproximar do americano e do europeu, o que significa novos desafios para a gestão dos resíduos. A legislação estabelece, como prioridade, reduzir o lixo na fonte e depois reutilizar e reciclar.

Além do poder público e das empresas, o comportamento da população é fundamental para a expansão do mercado da reciclagem. $\mathrm{O}$ governo tem o dever de criar regras e incentivos à essa prática, as prefeituras de fazer a coleta seletiva, e o meio empresarial de investir em logística reversa. A população, por sua vez, deve agir conscientemente, separando os resíduos para a coleta seletiva e exercendo o seu poder de compra, optando por produtos reciclados.

Nota-se que as mudanças ainda são lentas na diminuição do potencial poluidor do parque industrial brasileiro, principalmente no tocante às indústrias mais antigas, que continuam contribuindo com a maior parcela da carga poluidora gerada e elevado risco de acidentes ambientais, sendo necessários altos investimentos de controle ambiental e custos de despoluição para controlar a emissão de poluentes, o lançamento de efluentes e o depósito irregular de resíduos perigosos.

Os custos das empresas em proteção ambiental, incluindo reduçâo da poluição, gestão de resíduos, monitoramento, conformidade, impostos e seguros, têm aumentado rapidamente nos últimos anos, com regulamentaçáo ambiental crescente e mais exigente.

Por fim, ressalta-se que da mesma forma que os resíduos sólidos em geral (comuns e industriais) não podem ser descartados sem tratamento adequado e de maneira aleatória no meio ambiente, os restos de construçáo e demolição que contenham resíduos industriais incorporados também devem ter uma destinação final ambientalmente adequada. Mas, para isso, é imprescindível o controle e a fiscalização de todo o processo pelos órgãos governamentais. 


\section{Referências Bibliográficas}

AGÊNCIA BRASIL. Tratamento de residuos industriais no Brasil dobra em três anos. Publicado em 04/06/2009. Disponível em: <http://www.ecodesenvolvimento.org.br/ noticias/tratamento-de-residuos-industriais-no-brasil-dobra. Acesso em: 18 de fev. 2012>.

ASSOCIAÇÃO BRASILEIRA DE EMPRESAS DE LIMPEZA PÚBLICA E RESÍDUOS ESPECIAIS (Abelpre). Panorama dos resíduos sólidos no Brasil de 2014. Disponível em: $<$ http://www.abrelpe.org.br/panorama_edicoes.cfm>. Acesso em: 28 de jul. 2015.

ASSOCIAÇÃO BRASILEIRA DE NORMAS TÉCNICAS (ABNT). NBR 10.004 Residuos sólidos - Classificação. Rio de Janeiro, $2004 \mathrm{a}$.

ASSOCIAÇÃO BRASILEIRA DE NORMAS TÉCNICAS (ABNT). NBR 10.005 Procedimento para obtenção de extrato lixiviado de resíduos sólidos. Rio de Janeiro, 2004b.

ASSOCIAÇÃO BRASILEIRA DE NORMAS TÉCNICAS (ABNT). NBR 10.006 Procedimento para obtenção de extrato solubilizado de resíduos sólidos. Rio de Janeiro, 2004c.

BANCO MUNDIAL (World Bank). Hoornweg, D.; Bhada-Tata, P. (Org.). What a Waste: A Global Review of Solid Waste Management. World Bank: Washington, DC (EUA), 2012.

BRASIL (País) Ministério do meio Ambiente. Política Nacional de Resíduos Sólidos. Disponível em: <http://www.mma.gov.br/pol\%C3\%ADtica-de-res\%C3\%ADduoss\%C3\%B3lidos>. Acesso em 31 de jul. 2015.

CASAGRANDE JR, E. F. Inovação e sustentabilidade: possíveis ferramentas para uma necessária interface. Revista Educação e Tecnologia. Núcleo de Gestão Tecnológica da Universidade Federal do Paraná: Paraná 2004.

CIMM. O destino certo dos resíduos industriais. Publicado em 09/04/2010. Disponível em: <http://www.cimm.com.br/portal/noticia/exibir_noticia/6788-o-destino-certo-dosresduos-industriais $>$. Acesso em: $18 \mathrm{de} \mathrm{fev.2012.}$

CLÁUDIO, J. R. Resíduos sólidos perigosos - solidificação de lamas tóxicas com cimentos. Dissertação (Mestrado). Escola Politécnica, Universidade de São Paulo, São Paulo, 1987.

COMPANHIA DE TECNOLOGIA DE SANEAMENTO AMBIENTAL. Resíduos Sólidos Industriais. 1985.

COMPROMISSO EMPRESARIAL PARA RECICLAGEM. Cempre Review 2013. Cempre: São Paulo, 2013.

CONNER, J. R.; HOEFFNER, S. L. The history of stabilization/solidification technology. Critical Reviews in Environment Science and Technology, EUA, p. 325-396, 1998.

CONSELHO NACIONAL DO MEIO AMBIENTE. Resolução $n^{\circ} 307$. De 05 de julho de 2002.

DANIALI, S. Solidification/stabilization of heavy metals in latex modified Portland cement matrices. Journal of Hazardous Materials, v. 24, n. 2-3, p. 225-230, 1990.

EDWARDS, B. Guia básica de la sostenibilidad. Barcelona: Gustavo Gili, 2008.

FEDERAÇÃO DAS INDU̇STRIAS DO ESTADO DE SÃO PAULO (FIESP). Política Nacional de Resíduos Sólidos: Lei 12.305/2010 - Decreto 7.404/2010. Apresentação (Power point). Novembro de 2011. Disponível em: http://www.fiesp.com.br/arquivos/2011/ arquivos/pnrs_e_decreto.pdf. Acesso em: 17 de jan. 2012a. 
FEDERAÇÃO DAS INDU̇STRIAS DO ESTADO DE SÃO PAULO (FIESP). Resíduos Sólidos. Disponível em: <http://www.fiesp.com.br/ambiente/area_tematicas/residuos. aspx>. Acesso em: 18 de fev. 2012b.

HANNA, R. A. Estudo da estabilização por solidificação de produtos tóxicos em cimento Portland: uma análise em nivel microestrutural. Tese (Doutorado). Escola Politécnica, Universidade de São Paulo, São Paulo, 1996.

KIPERSTOCK, A. Tendências ambientais do setor automotivo: prevenção da poluição e oportunidade de negócio. Revista Nexus, Curso de mestrado em Economia da Universidade Federal da Bahia, setembro 2000.

KRAEMER, M. E. P. A questão ambiental e os resíduos industriais. 2012b. Disponível em: http://br.monografias.com/trabalhos/residuos-industriais/residuos-industriais.shtml. Acesso em 18 de fev. 2012.

KRAEMER, M. E. P. Como quantificar e contabilizar os residuos industriais. 2012a. Disponível em: <http://br.monografias.com/trabalhos/quantificar-residuos/quantificarresiduos.shtml>. Acesso em 18 de fev. 2012.

MACKAY, M.; EMERY, J. Stabilization/solidification of contamined soils and sludges using cimentitious systems. Cement Industry Solutions to Waste Management Proceedings, Calgary, p. 135, 1992.

PABLOS, J. M. Estudo para a reutilização do residuo sólido constituido pelas areias de fundição aglomeradas com argila, através da técnica de solidificaçãolestabilização em matrizes de cimento Portland, para aplicação no setor da construção civil. Tese (Doutorado). Escola de Engenharia de São Carlos, Universidade de São Paulo, São Carlos, 2008.

POON, C. S.; CLARK, A. I.; PERRY, R. Permeability study on the cement based solidification for the disposal of hazardous wastes. Cement and Concrete Reseach, EUA, v. 16, p. 161-172, 1986.

ROGERS, D.; TIBBEN-LEMBKE, R. An examination of reverse logistics practices. Journal of Business Logisticis, v. 22, n. 2, p. 129-148, 2001.

ROOM, J.J.; KOSELKA, P. R.; ALVARES JR, M. Empresas eco-eficientes. São Paulo: Editora Signus, 2004.

SANCHES, L. E. Desengenharia: o passivo ambiental na desativação de empreendimentos industriais. São Paulo: Editora Edusp, 2001.

SARTOR, C. E.; LAMBERTS, R. Habitare : resultados de impacto 1995/2007. Florianópolis: Coan Impressão Gráfica, 2008.

SMART CITIES (Revista). UE gera menos resíduos. Medialine: Lisboa (Portugal). Disponível em <http://www.smart-cities.pt/pt/noticia/ue-gera-menos-residuos-2603>. Acesso em: 28 de jul. 2015.

WARREN, D. S.; CLARK, A. I.; PERRY, R. A review of clay-aromatic interactions with a view to their use in hazardous waste disposal. Science Total Environment, v. 54, p. 157, 1986.

WORLD COMISSION ON ENVIRONMENTO AND DEVELOPMENT. Our commom future. Oxford Backpapers, 2007. 